DOI: $10.24014 /$ jush.v25i1.2560

\title{
INTEGRASI AGAMA DAN SAINS DALAM TAFSIR ILMI KEMENTERIAN AGAMA RI
}

\author{
Faizin \\ Universitas Islam Negeri Imam Bonjol Padang, Indonesia \\ faiz_lathif@yahoo.co.id
}

\begin{abstract}
The application of religious and scientific integration in the Tafsir Ilmi of Ministry of Religious Affairs was critically analyzed in this paper. The paradigm of religious and scientific integration was used in order to expose the building framework of the integration. Three forms of the integration paradigm were highlighted, namely: [1] scientific interpretation as one of the patterns of integration of religion and science, [2] theology as the basis of the integration, and [3] Tafsir Ilmi as an effort to present ethical values. The result of the study showed that Tafsir Ilmi was the one which was deductive-confirmatively implemented in the integration of religion and science. The pattern of religious and scientific integration had included theology as its basis in the Tafsir Ilmi, in which the theological side became central fusion of the Qur'anic text and the universe through the reading of tafsir and science. Metaphysical side was presented in order to bring the majesty of Allah SWT. The values of monotheism, science, and caliphs had an integral relationship and became instruments for the birth of the ethical values. Theological aspects and ethics looked thickly decorated in the pages of the Ilmi interpretation.
\end{abstract}

Keywords: Integration, Religion, Science, Tafsir Ilmi, Theology, and Ethics.

\begin{abstract}
Abstrak
Tulisan ini merupakan analisis kritis penerapan integrasi agama dan sains dalam Tafsir Ilmi Kementerian Agama RI. Paradigma integrasi agama dan sains digunakan untuk menyingkap bangunan integrasi dalam karya tersebut. Ada tiga bentuk paradigma integrasi yang disorot dalam tulisan ini, yakni: [1] tafsir ilmiah sebagai salah satu pola integrasi agama dan sains, [2] teologi sebagai basis integrasi, dan [3] Tafsir Ilmi sebagai upaya menghadirkan nilai-nilai etika. Hasil studi menunjukkan bahwa Tafsir Ilmi salah satu bentuk implementasi integrasi agama dan sains yang bersifat deduktif-konfirmatif. Pola integrasi agama dan sains dalam Tafsir Ilmi menjadikan teologi sebagai basisnya, di mana sisi teologis menjadi sentral perpaduan antara teks al-Qur'an dan alam semesta melalui pembacaan tafsir dan sains. Sisi metafisika dihadirkan dalam rangka menghadirkan keagungan Allah SWT. Nilai-nilai tauhid, ilmu pengetahuan, dan khalifah memiliki hubungan secara integral dan menjadi instrumen bagi lahirnya nilai-nilai etika. Aspek teologi dan etika terlihat kental menghiasi halaman demi halaman Tafsir Ilmi.
\end{abstract}

Kata kunci: Integrasi, Agama, Sains, Tafsir Ilmi, Teologi, dan Etika. 


\section{Pendahuluan}

Seyyed Hossein $\mathrm{Nasr}^{1}$ mendeskripsikan kejayaan umat Islam dalam bidang sains di masa silam melalui karya ilmuwan muslim, seperti Abu Nasr al-Farabi (w 950 M), Abu Alī al-Husain Ibn Sīnā (w 1037 M), Alī al-Hasan Ibn al-Hasan Ibn Haytham (w 1039 M), dan lain-lain, seolah-olah ia ingin merefleksikan bahwa umat Islam hari ini harus mengulang sejarah kejayaan silam melalui kemandirian sains.

Alternatif lain selain kemandirian sains adalah upaya melakukan integrasi keilmuan. Hal ini sangat memungkinkan, mengingat perkembangan ilmu pengetahuan dan teknologi dapat dijadikan pendekatan dalam mengeksplorasi ayat-ayat kauniyah yang jumlahnya mencapai 750-1000. Jumlah ini cukup banyak bila dibandingkan dengan ayat-ayat hukum yang hanya mencapai 250 ayat. $^{2}$ Wacana integrasi agama dan sains sudah menunjukkan gejala pergeseran yang signifikan, dari wilayah paradigma menuju tatanan aplikatif. Hal ini terlihat dari berbagai karya buah hasil paradigma integrasi tersebut. Basit Kareem Iqbal dan Elma Halder pada tahun 2000 menemukan 1.873.454 term "Islam and science"3 dalam media online dengan menggunakan search engine Altavista.com (sekarang yahoo.com). ${ }^{4}$ Sebagai perbandingan, pada 28 Desember 2016, 16:20 WIB penulis menemukan 402.000.000

\footnotetext{
${ }^{1}$ Seyyed Hossein Nasr, Science and Civilization in Islam (New York: New American Library,1970).

${ }^{2}$ Keterangan ini diperoleh dari Zaghlul al-Najjār yang dikutip dari Lajnah Pentashihan Mushaf al-Qur'an, Hewan dalam Perspektif al-Qur'an dan Sains (Jakarta: LPMA, 2012), xxiv.

${ }^{3}$ Penelitian ini berlanjut dengan mengambil sampel 132 situs secara random. Dari 132 situs diperoleh enam kategori penyajian Islam dan sains: [1] 31\% terkait konsep sains dalam al-Qur'an, [2] $18 \%$ tentang sejarah sains dalam Islam, [3] 5\% review buku, [4] 7\% institusi sains dan pusat kajian, [5] 29\% penjualan buku terkait Islam dan sains, dan [6] 10 mesin pencari atau situs yang ditujukan untuk link Islam and Science. Basit Kareem Iqbal dan Elma Halder, "Islam and Science Online", Islamic Studies 39, no. 4 (2000), http://www.jstor.org/stable/23076120, diakses 28 Desember 2016.

${ }^{4}$ AltaVista merupakan mesin pencari internet yang diperkenalkan tanggal 15 Desember 1995. Pada Februari 2003, AltaVista dibeli oleh Overture Services. Pada Juli 2003, Overture sendiri diambil alih oleh Yahoo. Lihat: http://www.putramelayu.web.id/2015/02/ mengenang-altavista-mesin-pencari-yang.html diakses 28 Des 2016.
}

term "Islam and science" dengan menggunakan mesin pencari yahoo.com. ${ }^{5}$ Artinya dalam 16 tahun terakhir, publikasi kategori Islam dan sains secara online telah mengalami perkembangan yang sangat pesat.

Salah satu buah karya nyata perkembangan tersebut di Indonesia adalah Tafsir Ilmi Kementerian Agama RI (selanjutnya disingkat dengan Tafsir Ilmi). Hal ini sekaligus menjadi salah satu bukti bahwa problem dikotomi ilmu yang sempat dikhawatirkan oleh para ilmuwan abad ke-21 tidak lagi merupakan perdebatan yang serius, baik dalam tatanan konsep, teori, paradigma, landasan filosofis, maupun penerapannya dalam dunia pendidikan. Tulisan ini ingin melihat secara kritis pola penerapan integrasi agama dan sains dalam Tafsir Ilmi melalui konten analisis. Dengan menggunakan paradigma integrasi agama dan sains sebagai objek formal, penelitian ini diharapkan mampu menyingkap bangunan pola integrasi dalam Tafsir Ilmi yang dalam hal ini dijadikan sebagai objek material. ${ }^{6}$

\section{Kerangka Teoretis: Diskursus Paradigma Integrasi Agama dan Sains}

Wacana integrasi agama dan sains telah melahirkan arus diskursus yang begitu deras, baik dari tradisi Barat maupun Timur, tidak terkecuali di Indonesia. Di Barat, Ian G. Barbour, dinilai memiliki andil besar dalam persoalan ini. Ia dianggap sebagai peletak dasar wacana integrasi sains dan agama. Melalui buku "When Science Meets Religion, ia kemudian menempatkan integrasi sebagai solusi yang ideal bagi perjumpaan sains dan agama. ${ }^{7}$ Ia berpandangan bahwa desain

\footnotetext{
${ }^{5}$ https://search.yahoo.com diakses 28 Des 2016 dengan menggunakan kata kunci "Islam and Science".

${ }^{6}$ Kaelan, Metode Penelitian Agama Kualitatif Interdisipliner (Yogyakarta: Paradigma, 2010), 40-48.

${ }^{7}$ Ian G. Barbour membagi pola hubungan sains dan agama menjadi empat, yakni: konflik, independen, dialogis, dan integrasi: [1] Konflik: agama dan sains adalah dua hal yang berbeda dan bahkan bisa bertentangan. Agama dan sains adalah entitas yang berbeda yang tidak bisa dipertemukan, baik secara ontologis, epistemologis, atau bahkan secara aksiologis. [2]
} 
alam menjadi bukti keberadaan Tuhan yang diperoleh dari kesadaran ilmu pengetahuan. Dalam kata lain, teologi memang berada di luar sains, tetapi teori ilmiah dapat mempengaruhi formulasi doktrin-doktrin tertentu. Dalam sintesis sistematis, sains dan agama berkontribusi pada pengembangan metafisika inklusif. ${ }^{8}$ Ian G. Barbour meyakini bahwa integrasi yang lebih sistematis dapat terjadi jika ilmu pengetahuan dan agama yang berkontribusi dalam metafisika komprehensif. Metafisika menurutnya adalah pencarian untuk satu set konsep umum dalam hal mana aspek-aspek yang berbeda dari realitas dapat ditafsirkan. Dalam artian bahwa konsep metafisika sesungguhnya menjadi landasan bagi bangunan integrasi sains dan agama yang dapat menjembatani terhubungnya pengetahuan transenden dan imanen.

Arthur Peacock ${ }^{9}$ seorang teolog Kristen kontemporer melihat bahwa pertemuan agama dan sains bagaikan pembangunan sebuah jembatan. Setelah jembatan selesai memungkinkan bagi kedua belah pihak untuk saling berinteraksi, sejalan dan sekata, bahkan secara maksimal keduanya dapat menyatu dalam format integrasi. Arthur menginginkan adanya kehadiran wujud Tuhan dalam segala aspek kehidupan, tidak terkecuali dalam sains. Dialog antara ilmu pengetahuan dan teknologi dengan Tuhan merupakan proses rasional, konsisten, dan kreatif dalam melahirkan kebaruan, keragaman, dan kompleksitas. Ini kemudian memperlihatkan eksistensi Tuhan dalam sifatsifat ciptaan-Nya.

Independen: Sains dan agama punya wilayah kerja berbeda, metode yang berbeda, dan kebenarannya berbeda pula, sehingga tidak perlu ada hubungan atau konflik antara keduanya. [3] Dialog: Model ini bermaksud mencari persamaan atau perbedaan secara metodis dan konseptual antara agama dan sains. [4] Integrasi: Model ini berusaha mencari titik temu pada masalahmasalah yang dianggap bertentangan antara keduanya. Lihat: Ian G. Barbour, When Science Meets Religion (New York: Harper Collins Francisco, 1998), 7-26.

${ }^{8}$ Ibid., 19-20.

${ }^{9}$ Arthur Peacock, Paths From Science Towards God (New York: One world Publications, 2001), 18-19.
Ken Wilber ${ }^{10}$ memetakan lima sikap terkait integrasi agama dan sains yang selama ini berkembang, yakni: [1] sains menyangkal validitas agama, [2] agama menyangkal validitas sains, [3] sains salah satu model valid dalam pengetahuan sehingga dapat berdamai dengan pengetahuan spiritual, [4] sains memiliki argumen tersendiri tentang eksistensi roh, dan [5] sains bukan pengetahuan tentang dunia, tetapi lebih pada interpretasi terhadap dunia, oleh sebab itu validitas sains sama dengan validitas seni dan puisi. Melihat lima persoalan di atas Wilber kemudian menawarkan solusi bagaimana semestinya sains dan agama dapat berkolaborasi dan berintegrasi secara sinergis. Ia mengajukan teori three strands of valid knowing ${ }^{11}$ yang berfungsi memverifikasi seluruh pengetahuan. Teori ini merupakan jalan bagi ilmu pengetahuan untuk memperoleh pengetahuan yang valid: [1] Practical injunction or exemplar atau tindakan langsung verifikasi melalui contoh, paradigma, eksperimen, dan aturan praktis. [2] Direct apprehension, illumination, or experience (pendekatan/penelitian langsung, iluminasi, atau pengalaman), yaitu dengan melakukan penelitian langsung untuk memperoleh sejumlah data hipotetik dari pengalaman fisik (physical data) dan pengalaman mental (mental data), dan [3] Communal checking either rejection or confirmation, yakni proses pemeriksaan atas hasil (data dan bukti), baik untuk tujuan penolakan hasil atau persetujuan/penguatan. Proses ini disebut juga dengan istilah falsifikasi. Pengetahuan yang ia maksud tidak saja pengetahuan empiris, namun juga dimensi mental dan spiritual. Pada dimensi mental dan spiritual tentu akan berbenturan dengan persoalan bukti yang menjadi syarat utama

\footnotetext{
${ }^{10} \mathrm{Ken}$ Wilber, The Marriage of Sense and Soul: Integrating Science and Religion (New York: Random House, 1998), 100106.

${ }^{11}$ Ibid., 14; lihat juga: Efron Lumban Gaol. "Integrasi Sains dan Agama: Sebuah Tawaran dari Ken Wilber untuk Zaman Ini", MELINTAS 28, no. 3 (2012), http://journal.unpar.ac.id/index. php/melintas/article/viewFile/274/259, diakses 21 Desember 2016 ,
} 
bagi ilmu pengetahuan. Solusi yang tepat untuk persoalan ini adalah mengambil jalan tengah, di mana kedua belah pihak harus membuka diri: sains harus membuat citra diri secara akurat di satu sisi dan agama harus menerima citra diri secara otentik di sisi lain.

Ilmuwan muslim yang dipandang banyak menyita waktu dalam kajian hubungan agama dan sains, atau populer dengan integrasi sains dan Islam di antaranya adalah Seyyed Hossein Nasr, M. Naquib al-Attas, Ismail Raji' Faruqi, Ziauddin Sardar. Selain tokoh di atas juga dikenal Mehdi Ghalsani, yang melihat perjumpaan sains dan Islam melalui key word al-Qur'an. Semua bergerak terutama pada wilayah epistemologi keilmuan sains dalam Islam, di samping aspek metafisika. $^{12}$

Seyyed Muhammad Naquib al-Attas, sebagaimana dijelaskan oleh Suwendi, ${ }^{13}$ menawarkan proyek Islamisasi ilmu sebagai upaya filosofis untuk memisahkan ilmu dari tendensi magis, mitos, dan budaya sekuler. Langkah Islamisasi Ilmu oleh al-Attas dibagi menjadi dua tahapan yakni: [1] the dewesternization of knowledge: pemisahan elemen-elemen dan konsep-konsep kunci yang membentuk kebudayaan dan peradaban Barat dari setiap cabang ilmu pengetahuan. [2] the Islamization of knowledge: pemasukan elemen-elemen Islam dan konsep-konsep kunci ke setiap cabang ilmu pengetahuan yang relevan.

Tidak jauh berbeda dengan dua tokoh sebelumnya, Ziauddin Sardar berangkat dari kegelisahannya tentang keterbelakangan negaranegara muslim yang pernah ia kunjungi dalam tahun 1970-1980. ${ }^{14}$ Satu sisi negara muslim tertinggal dalam hal ilmu pengetahuan dan

\footnotetext{
${ }^{12}$ Zainal Abidin Bagir, dkk (ed.), Integrasi Ilmu dan Agama: Interpretasi dan Aksi (Bandung: Mizan, 2005), 24.

${ }^{13}$ Suwendi, "Islamisasi Ilmu: Studi atas Konsep dan Praktek Pendidikan Syed Muhammad Nuqaib al-Attas" (Disertasi: Sekolah Pascasarjana UIN Syarif Hidayatullah Jakarta, 2008).

${ }^{14}$ Ehsan Masood dalam pengantar buku Ziauddin Sardar dan Ehsan Masood, How Do You Know: Reading Ziauddin Sardar on Islam, Science and Cultural Relations (London: Pluto Press, 2006), 1.
}

teknologi, di sisi lain keberadaan pengetahuan Barat dianggap tidak mampu memenuhi kebutuhan materi, kultural, dan spiritual masyarakat muslim. Untuk persoalan kedua Sardar menawarkan epistemologi Islam yang berangkat dari prinsipprinsip tauhid, di mana tauhid menjadi poros bagi semua cabang ilmu pengetahuan, termasuk sains.

Selain tokoh-tokoh yang disebutkan di atas, di Indonesia terdapat beberapa tokoh yang aktif dan produktif menyuarakan wacana integrasi sains dan Islam, di antaranya: Kuntowijoyo ${ }^{15}$ Mulyadhi Kartanegara, ${ }^{16}$ M. Amin Abdullah, ${ }^{17}$ dan beberapa tokoh lain. ${ }^{18}$ Kuntowijoyo menitikberatkan bahasan integrasi ilmu pada apa yang ia sebut sebagai "pengilmuan Islam", yakni upaya integrasi rasionalitas pengetahuan manusia dengan wahyu Tuhan ${ }^{19}$ dan usaha objektivikasi ilmu sebagai interpretasi nilai-nilai Islam untuk diinternalisasikan ke dalam kategori-kategori objektif yang relevan.

Teori integratif holistik yang digagas oleh Mulyadhi Kartanegara menarik juga diungkapkan dalam bahasan ini. Ide ini lahir dilatarbelakangi oleh kebutuhan pengembangan keilmuan di Indonesia, khususnya di Perguruan Tinggi Agama Islam dan berangkat dari kegelisahan akademiknya menyangkut problem dikotomi antara ilmu umum dan ilmu agama. ${ }^{20}$ Basis integrasi holistik berangkat dari ajaran wahdat

\footnotetext{
${ }^{15}$ Kuntowijoyo, Islam Sebagai Ilmu: Epistemology, Metodologi dan Etika (Bandung: Teraju, Mizan Media Utama 2004).

${ }^{16}$ Mulyadhi Kartanegara, Integrasi Ilmu: Sebuah Rekonstruksi Holistik (Jakarta: UIN Jakarta Press, 2005).

${ }^{17}$ M. Amin Abdullah. Islamic Studies di Perguruan Tinggi: Pendekatan Integratif-Interkoneksi (Yogyakarta: Pustaka Pelajar, 2006).

${ }^{18}$ Tokoh tersebut di antaranya adalah: Imaduddin Abdurrahim, Mochtar Naim, Jalaluddin Rahmat, Azyumardi Azra, dan Armahedi Mazhar. Lihat: Saifuddin Zuhri, "Integrasi Biologi dan Agama dalam Perspektif Islam" (Disertasi: Sekolah Pascasarjana UIN Syarif Hidayatullah Jakarta, 2009), 16.

${ }^{19}$ Kusmana berkesimpulan bahwa Kuntowijoyo memiliki kecenderungan konstruksi ilmu pengetahuan dengan inspirasi input Qurani, yang ia sebut sebagai paradigma al-Qur'an, lihat: Kusmana. "Paradigma al-Qur'an: Model Analisis Tafsir Maqashidi dalam Pemikiran Kuntowijoyo", Afkaruna 11, no. 2 (2015): 220-239. http://journal.umy.ac.id/index.php/afkaruna/ article/viewFile/2210/2147, diakses 25 Desember 2016. 20Mulyadhi Kartanegara, 19-30.
} 
al-wujūd yang memandang bahwa wujud-wujud yang mengilhami hirarki wujud itu merupakan suatu yang integral yang tidak bisa dipisahkan satu sama lain. Oleh karena itu, secara holistik semua objek mempunyai status ontologis yang sama, baik objek fisik maupun metafisik. ${ }^{21}$

Selain landasan integrasi ilmu, objek dan sumber ilmu, Mulyadhi juga menawarkan integrasi bidang-bidang ilmu (metafisika, fisika, dan matematika) metode dan penjelasan ilmiah, pengalaman manusia, serta integrasi ilmu-ilmu praktis dan teoretis. Semua ini oleh Mulyadhi merupakan level kerja epistemologi yang dapat diklasifikasikan menjadi dua, yakni pembagian ilmu dan metodologi ilmiah. Pada kedua level ini, meskipun secara epistemologi memiliki perbedaan, namun secara substansi ilmu-ilmu itu sama, sehingga proses integrasi dapat secara leluasa berinteraksi dan bekerjasama.

M. Amin Abdullah mewakili tokoh Islam Indonesia kontemporer juga aktif menyuarakan paradigma integrasi keilmuan, tidak saja dalam masalah konsep, namun juga implementasinya dalam dunia pendidikan Islam, khususnya di UIN Sunan Kalijaga. M. Amin Abdullah melalui proyek integrasi-interkoneksi mengusung paradigma teoantroposentris-integratif. ${ }^{22}$ Dalam bangunan integrasi-interkoneksi memungkinkan terjadinya dialog antara tiga peradaban keilmuan sekaligus, yakni hadārah al-nash (tradisi teks), hadārah al-'ilm (tradisi ilmu), dan hadārah al-falsafah (tradisi filsafat). Perpaduan tiga peradaban keilmuan ini berangkat dari paradigma teoantroposentris, yang secara epistemologis tidak akan melahirkan sikap diskriminatif dan dikotomis, baik aspek eksistensi teologis maupun

\footnotetext{
${ }^{21}$ Ibid., 35

${ }^{22}$ Menurut hasil kajian Parluhutan Siregar bahwa pemikiran M. Amin Abdullah ini tidak berangkat dari ruang hampa, melainkan hasil analisis dan sintesis dari berbagai pemikiran sarjana sebelumnya, baik dari kalangan Islam maupun Barat. Lihat: Parluhutan Siregar. "Integrasi Ilmu-ilmu Keislaman dalam Perspektif M. Amin Abdullah", MIQOT: Jurnal Ilmuilmu Keislaman 38, no.2 (2014), http://www.jurnalmiqotojs. uinsu.ac.id/index.php/jurnalmiqot/article/view/66, diakses 21 Desember 2016.
}

humanis. Sementara integratif merupakan implementasi epistemologi keilmuan Islam, yakni: epistemologi bayāniy, burhaniy, dan 'irfani yang dapat bekerja secara metodis pada wilayah ilmu-ilmu agama (Islamic studies/'ulüm al-dinn) dan ilmu-ilmu umum (ilmu sosial, ilmu alam, dan humaniora). Konsep ini kemudian dituangkan dalam jaring laba-laba keilmuan. ${ }^{23} \mathrm{M}$. Amin Abdullah pada intinya ingin menunjukkan bahwa ilmu agama dapat saling menyapa dengan ilmu umum lainnya, bersinergi dalam memberikan manfaat bagi bangunan peradaban Islam kontemporer.

Dari diskusi panjang tentang paradigma integrasi keilmuan yang dikembangkan oleh para ilmuwan di atas, baik dari tradisi Barat maupun Timur, termasuk tradisi keilmuan di Indonesia, pada intinya ingin menempatkan sikap keterbukaan ilmu dan dialog sebagai sesuatu yang tidak terpisah antara agama dan ilmu pengetahuan. Hal ini bukan sekedar membuktikan kegagalan positivisme dalam meruntuhkan metafisika atau mengakhiri dikotomi ilmu, akan tetapi lebih pada menemukan signifikansi epistemologi keilmuan Islam dan kesadaran akan pentingnya rekonstruksi ilmu bagi kemajuan peradaban.

Dari paradigma integrasi yang dikemukakan di atas, ada beberapa konsep yang dapat ditarik untuk kemudian dapat dijadikan instrumen dalam melihat integrasi keilmuan dalam ranah implementasi pada Tafsir Ilmi Kementerian Agama, yakni: [1] upaya memadukan berbagai bidang keilmuan dalam menjelaskan suatu fenomena secara integral, [2] teologi (tauhid) sebagai basis integrasi, dan [3] upaya menghadirkan etika agar ilmu tidak bebas nilai. Hal ini senada dengan kesimpulan Muzaffar Iqbal, bahwa Islam dan sains modern memiliki tiga kategori, yakni: epistemologis, ontologis/metafisik, dan etika. ${ }^{24}$ Secara sederhana paradigma integrasi keilmuan dapat dipetakan

\footnotetext{
${ }^{23}$ M. Amin Abdullah. Islamic Studies di Perguruan Tinggi: Pendekatan Integratif-Interkoneksi.

${ }^{24}$ Muzaffar Iqbal, Making of Islamic Science (London: Greenwood Press, 2007), 198.
} 
melalui diagram di bawah ini:

Diagram 1. Integrasi Keilmuan

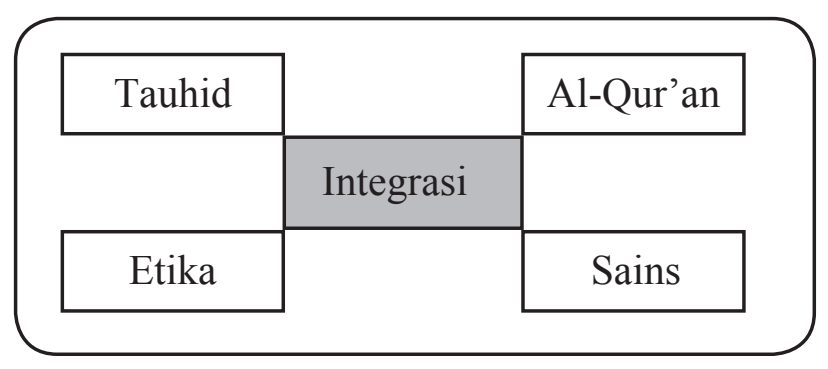

\section{Deskripsi Tafsir Ilmi Kementerian Agama RI}

Tafsir Ilmi Kementerian Agama merupakan karya hasil perpaduan tafsir al-Qur'an dengan ilmu pengetahuan modern (baca sains) yang digagas oleh Kementerian Agama RI melalui Bidang Litbang dan Diklat yang dilaksanakan oleh Lajnah Pentashihan Mushaf al-Qur'an (LPMA) bekerjasama dengan Lembaga Ilmu Pengetahuan Indonesia (LIPI). Bisa dikatakan bahwa karya ini adalah karya pertama pemerintah Indonesia di bidang tafsir yang bercorak saintifik (al-launi al-'ilmi). ${ }^{25}$

Selain bercorak saintifik, Tafsir Ilmi menggunakan metode tematik (mawdhu'i) dengan mengambil beberapa tema terkait tafsir alQur'an dan ilmu pengetahuan. Menurut Mustafa Muslim ${ }^{26}$ sepertinya Tafsir Ilmi mengadopsi varian tafsir tematik berdasarkan tema-tema yang disajikan al-Qur'an. Hal ini dapat dilihat dari 16

\footnotetext{
${ }^{25}$ Corak tafsir ilmiah atau saintifik adalah pemahaman teks alQur'an dengan menjadikan data-data ilmiah sebagai variabel penjelas dalam memahami ayat-ayat al-Qur'an; lihat, Islah Gusmian, Khazanah Tafsir Indonesia: Dari Hermeneutika Hingga Ideologi (Yogyakarta: LKiS, 2013), 247

${ }^{26}$ Menurut Mushthafa Muslim metode ini memiliki tiga bentuk, yaitu: [1] tafsir tematik berdasarkan kata yang terdapat di dalam alQur'an, [2] tafsir tematik berdasarkan tema-tema yang disajikan al-Qur'an, baik yang dipahami dari bahasa teks, seperti: hidayah dalam al-Qur'an, maupun dari pembahasan kontekstual (seperti: nasionalisme dalam perspektif al-Qur'an), dan [3] tafsir tematik yang sasaran utama dan tema-tema pokok arah pembicaraan satu surat tertentu (seperti: tafsir surat al-fatihah atau konsep iman dalam surat al-Fatihah). Sementara itu, dari tiga jenis varian ini Abdul Mustaqim menambahkan varian keempat, yakni tematik tokoh, artinya tema al-Qur'an diteliti melalui pemikiran tokoh, contohnya: Jilbab menurut M. Quraish Shihab dalam tafsir alMishbah. Lihat, Mushthafa Muslim, Mabāhits fi al-Tafsìr alMawdhū'iy (Dimāsyq: Dār al-Qalm, 1989), 23-28; bandingkan dengan Abdul Mustaqim, Metode Penelitian al-Qur'an dan Tafsir, (Yogyakarta: Idea Press, 2015), 61-63.
}

tema Tafsir Ilmi yang diangkat, lebih jelas dapat dilihat pada tabel 1 .

Tafsir Ilmi yang digagas pada tahun 2009 telah menghasilkan 10 tema penting terkait al-Qur'an dan sains yang diterbitkan tahun berikutnya. Proyek ini kemudian berlanjut, terhitung hingga tahun 2015 Lajnah Pentashihan Mushhaf alQur'an telah menerbitkan 16 karya Tafsir Ilmi. Di antara karya tersebut dapat dilihat dalam tabel di bawah ini:

Tabel 1. Tafsir Ilmi Kementerian Agama RI

\begin{tabular}{|c|l|c|}
\hline No & \multicolumn{1}{|c|}{ Judul } & $\begin{array}{c}\text { Tahun } \\
\text { Terbit }\end{array}$ \\
\hline 1. & $\begin{array}{l}\text { Penciptaan Jagad Raya dalam } \\
\text { Perspektif al-Qur'an dan Sains }\end{array}$ & 2010 \\
\hline 2. & $\begin{array}{l}\text { Penciptaan Bumi dalam Perspektif } \\
\text { al-Qur'an dan Sains }\end{array}$ & 2010 \\
\hline 3. & $\begin{array}{l}\text { Penciptaan Manusia dalam } \\
\text { Perspektif al-Qur'an dan Sains }\end{array}$ & 2010 \\
\hline 4. & $\begin{array}{l}\text { Air dalam Perspektif al-Qur'an dan } \\
\text { Sains }\end{array}$ & 2010 \\
\hline 5. & $\begin{array}{l}\text { Tumbuhan dalam Perspektif al- } \\
\text { Qur'an dan Sains }\end{array}$ & 2010 \\
\hline 6. & $\begin{array}{l}\text { Kiamat dalam Perspektif al-Qur'an } \\
\text { dan Sains }\end{array}$ & 2010 \\
\hline 7. & $\begin{array}{l}\text { Hewan dalam Perspektif al-Qur'an } \\
\text { dan Sains }\end{array}$ & 2012 \\
\hline 8. & $\begin{array}{l}\text { Kisah Para Nabi Pra-Ibrahim dalam } \\
\text { Perspektif al-Qur'an dan Sains }\end{array}$ & 2012 \\
\hline 9. & $\begin{array}{l}\text { Seksualitas dalam Perspektif al- } \\
\text { Qur'an dan Sains }\end{array}$ & 2012 \\
\hline 10. & $\begin{array}{l}\text { Manfaat Benda-benda Langit dalam } \\
\text { Perspektif al-Qur'an dan Sains }\end{array}$ & 2012 \\
\hline 11. & $\begin{array}{l}\text { Makanan dan Minuman dalam } \\
\text { Perspektif al-Qur'an dan Sains }\end{array}$ & 2013 \\
\hline 12. & $\begin{array}{l}\text { Samudra dalam Perspektif al-Qur'an } \\
\text { dan Sains }\end{array}$ & 2013 \\
\hline 13. & $\begin{array}{l}\text { Waktu dalam Perspektif al-Qur'an } \\
\text { dan Sains }\end{array}$ & $\begin{array}{l}\text { Semesta dalam Perspektif al-Qur'an } \\
\text { dan Sains }\end{array}$ \\
\hline 15. & $\begin{array}{l}\text { Jasad Renik dalam Perspektif al- } \\
\text { Qur'an dan Sains }\end{array}$ \\
\hline 16. & $\begin{array}{l}\text { Kepunahan Makhluk Hidup dalam } \\
\text { Perspektif al-Qur'an dan Sains }\end{array}$ \\
\hline 14. & $\begin{array}{l}\text { Eksistensi Kehidupan di Alam } \\
\text { Sala }\end{array}$ \\
\hline
\end{tabular}

Dari rangkaian sambutan yang disampaikan, baik oleh Menteri Agama, Kepala Litbang, Kepala LIPI, dan Kepala LPMA, ${ }^{27}$ diketahui bahwa

\footnotetext{
${ }^{27}$ Semua karya Tafsir Ilmi memuat sambutan dari beberapa institusi terlibat, kecuali terbitan tahun 2010 yang tidak memuat
} 
kehadiran Tafsir Ilmi di tengah-tengah masyarakat Indonesia dilatarbelakangi oleh beberapa alasan, yakni: [1] respon terhadap perkembangan ilmu pengetahuan dan teknologi, [2] kesadaran iqra' sebagai upaya pengkajian terhadap al-Qur'an melalui ilmu pengetahuan modern yang bertujuan untuk memperkokoh keimanan, [3] sebagai salah satu model mengenalkan Tuhan kepada manusia modern, dan [4] menjadikan al-Qur'an sebagai paradigma dan dasar yang memberi makna spiritual kepada ilmu pengetahuan \& teknologi agar tidak bebas nilai dan sekuler. Latar belakang penulisan Tafsir Ilmi di atas setidaknya memiliki tiga wilayah kerja ilmu secara sinergis, yaitu: [1] ingin menanamkan nilai-nilai transendental melalui pembacaan al-Qur'an dan sains, yang diharapkan mampu menggugah dan mengukuhkan keyakinan manusia untuk meyakini kebesaran Tuhan, [2] adanya keinginan untuk memberikan aksiologi ilmu bagi sains modern agar tidak bebas nilai dan tetap berada pada pusaran etika ilmu pengetahuan, dan [3] ingin menunjukkan secara eksplisit adanya integrasi keilmuan, khususnya antara Islam (tafsir al-Qur'an) dan penemuan ilmiah modern yang dapat memberi kontribusi bagi perkembangan ilmu dan teknologi modern. Selain latar belakang di atas, penulisan Tafsir Ilmi juga dimotivasi oleh adanya keinginan untuk membangun peradaban Islam yang digagas melalui perjumpaan ilmu pengetahuan dan tafsir. ${ }^{28}$

Otoritas Tafsir Ilmi sebagai produk integrasi tafsir al-Qur'an dan sains dapat dilihat dari author (baca: tim penulis) yang ikut terlibat dalam penulisan. Tim penulis karya momental ini terdiri dari tim syar'i dan tim kauni. Tim syar'i adalah ulama al-Qur'an yang diketahui telah lama dan banyak bergelut di bidang alQur'an dan tafsirnya, umumnya mereka berasal

sambutan Menteri Agama. Lihat: Lajnah Pentashihan Mushaf alQur'an, Hewan dalam Perspektif al-Qur'an dan Sains (Jakarta: LPMA, 2012), ix-xviii.

${ }^{28}$ Muchlis M. Hanafi, "Memahami Isyarat-isyarat Ilmiah alQur'an: Sebuah Pengantar" dalam Lajnah Pentashihan Mushaf al-Qur'an, Hewan dalam Perspektif al-Qur'an dan Sains (Jakarta: LPMA, 2012), xxii. dari kalangan akademisi, seperti Ahsin Sakho Muhammad, Syibli Sarjaya, Muchlis M. Hanafi, Hamdani Anwar, dan Darwis Hude. Sementara tim kauni adalah para saintis yang berasal dari Lembaga Ilmu Pengetahuan Indonesia (LIPI), Lembaga Pengembangan dan Antariksa Nasional (LAPAN), dan Bosscha Institut Teknologi Bandung (ITB), mereka adalah para ilmuwan dan akademisi yang cukup dikenal dengan beragam latar belakang keilmuan, di antaranya: Herry Harjono, Thomas Djamaluddin, Mudji Haharto, Umar Anggara Jenie, Arie Budiman, dan lain-lain. Artinya, kolaborasi antara ulama al-Qur'an dan saintis dipandang kapabel dalam produksi Tafsir Ilmi. Hal ini kemudian ditunjang oleh sistem kerja sama yang baik melalui ijtihad kolektif (ijtihād jamā'i $)^{29}$ dan semua tim tunduk pada prinsip dasar penyusunan yang telah dirumuskan. ${ }^{30}$

\section{Implementasi Paradigma Integrasi dalam Tafsir Ilmi}

Berdasarkan paradigma epistemologi yang dijelaskan sebelumnya, bagian ini akan melihat secara kritis implementasi integrasi al-Qur'an dan sains dalam Tafsir Ilmi.

\section{Tafsir Ilmi: Antara Tafsir Ilmiah dan Integrasi Keilmuan}

Tafsir ilmiah (al-tafsir al- 'ilmi/ scientific exegesis) oleh Muhammad Husain al-Dzahabi didefinisikan sebagai pembahasan tentang aspek-aspek ilmu pengetahuan yang terdapat

\footnotetext{
${ }^{29}$ Lajnah Pentashihan Mushhaf al-Qur'an, Hewan dalam Perspektif al-Qur'an dan Sains, xii, xiv, xviii.

${ }^{30}$ Menurut Muchlis M. Hanafi, ada tujuh prinsip dasar penyusunan Tafsir Ilmi, secara ringkas dapat disebutkan sebagai berikut: [1] Memperhatikan arti dan kaedah kebahasaan, [2] Memperhatikan konteks ayat yang ditafsirkan. [3] Memperhatikan hasil penafsiran Rasul, sahabat, tabi'in, dan ulama tafsir, serta memahami ulum al-Qur'an, [4] Tidak menggunakan ayat untuk menghukum benar atau salah sebuah temuan ilmiah, [5] Memperhatikan makna musytarak dari sebuah kata, [6] Memahami isyarat ilmiah hendaknya memahami benar objek bahasan ayat, dan [7] Menggunakan temuan ilmiah yang telah mencapai tingkat hakikat, bukan teori atau hipotesis yang belum teruji. Lihat, Muchlis M. Hanafi, "Memahami Isyarat-isyarat Ilmiah al-Qur'an: Sebuah Pengantar" dalam Lajnah Pentashihan Mushaf al-Qur'an, Hewan dalam Perspektif al-Qur'an dan Sains, xxv-xxvii.
} 
di dalam al-Qur'an serta upaya menyingkap berbagai pengetahuan dan pemikiran yang terkandung di dalamnya. ${ }^{31}$ Dalam pandangan al-Dzahabi tafsir ilmiah dipahami sebagai upaya memahami al-Qur'an melalui temuan ilmiah, baik secara induktif ataupun deduktif. Secara induktif, al-Qur'an ditempatkan sebagai landasan untuk melakukan penelitian ilmiah, atau dalam bahasa lain data-data alQur'an dijadikan sebagai data primer untuk kemudian data-data itu dibuktikan melalui penelitian ilmiah. Secara deduktif, penelitian ilmiah sebelumnya tidak berangkat dari ayat-ayat al-Qur'an, setelah terbukti secara ilmiah hasil penelitian tersebut dicarikan konfirmasinya melalui ayat-ayat al-Quran yang relevan.

Pandangan ini pada dasarnya merupakan pendekatan integratif, ayat al-Qur'an di satu sisi dan temuan ilmiah di sisi lain. Secara prinsip, model ini memang tidak ada persoalan karena sains yang dinamis memiliki relevansi dengan ayat-ayat al-Qur'an. Meskipun pada akhirnya klaim kebenaran mutlak tetap ada pada kitab suci sementara kebenaran sains dicitrakan sebagai suatu yang relatif. Baik saintis maupun ulama, harus berdalih bahwa tafsir ilmiah tidak dalam rangka menjustifikasi kebenaran yang relatif itu dengan kebenaran absolut atau tafsir ilmiah tidak untuk memaksakan tafsir al-Qur'an seolah sesuai dengan temuan sains. ${ }^{32}$ Di sinilah wilayah kerja Tafsir Ilmi berperan dalam menyingkap isyarat ilmiah dan membuktikan isyaratisyarat itu melalui temuan sains modern. Di sini juga terlihat adanya keterbukaan umat Islam dalam menerima ilmu pengetahuan modern sebagai sesuatu yang tidak terpisah dari Islam dan bahkan ia merupakan bagian

\footnotetext{
${ }^{31}$ Muhammad al-Said Husain al-Dzahabi, al-Tafsìr wa alMufassirūn (Al-Qāhirah: Maktabah Wahbah, tth [Maktabah Syamilah]), 349.

${ }^{32}$ Lajnah Pentashihan Mushhaf al-Qur'an, Hewan dalam Perspektif al-Qur'an dan Sains, hlm. xxvii
}

dari anugerah Tuhan yang patut disyukuri dan ditadabburi.

Bagi Kuntowijoyo, proyek Islamisasi ilmu tidak mesti diterjemahkan sebagai penyangkalan warisan intelektual yang lahir dari peradaban lain, termasuk Barat. Rekonstruksi ilmu pengetahuan dalam peradaban Islam tidak berangkat dari ruang hampa. Kehadirannya adalah buah dari pertarungan epistemologi. Khazanah keilmuan Barat dalam hal ini dapat dimanfaatkan untuk kepentingan umat Islam, hal ini tentu setelah melewati proses seleksi dan adaptasi secara objektif. ${ }^{33}$

Menarik disimak adalah pemikiran Ken Wilber yang cenderung mengukuhkan paradigma posmodern sebagai landasan integrasi, di mana masing-masing ilmu diberi wewenang untuk menentukan metode validasinya masing-masing. Selain itu, baik agama maupun sains jika ingin bersama-sama tumbuh dan berkembang, maka keduanya harus membuka diri. Sebab, kemajuan ilmu pengetahuan amat ditentukan oleh sejauhmana suatu teori dapat berdialog dengan teori lainnya sehingga dapat memperkokoh bangunan ilmiah. Dialektika ilmiah yang berlangsung secara terus menerus dan berkesinambungan, merupakan proses transendensi menuju pemahaman kebenaran absolut-transendental. ${ }^{34}$

Tafsir Ilmi Kementerian Agama pada prinsipnya menggunakan pola deduktifkonfirmatif. Hal ini dapat dilihat dalam berbagai tema yang disajikan, sebagai contoh “Adam mampu menjelaskan nama-nama benda" ${ }^{35}$ seperti firman Allah dalam QS. al-

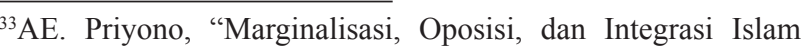
Indonesia: Menyimak Pemikiran Dr. Kuntowijoyo", dalam AE. Priyono (ed.), Paradigma Islam: Interpretasi untuk Aksi (Bandung: Mizan, 2008), 62.

${ }^{34}$ Fuad, dkk, "Kebenaran Ilmiah dalam Pemikiran Thomas S. Kuhn dan Karl R. Popper: Suatu Kajian Hermeneutika dan Kontribusinya bagi Masa Depan Ilmu", Jurnal Filsafat 23, no. 2 (2015): 252-276, https://jurnal.ugm.ac.id/wisdom/article/ view/12684/9119, diakses 21 Desember 2016.

${ }^{35}$ Lajnah Pentashihan Mushhaf al-Qur'an, Kisah Para Nabi PraIbrahim dalam perspektif al-Qur'an dan Sains (Jakarta: LPMA, 2012), 30-34.
} 
Baqarah (2): 31.

Kemampuan Adam dalam menjelaskan nama-nama benda terkait dengan unsur ciptaan, ia diciptakan dari tanah. Kenyataan ini berbeda dengan malaikat yang diciptakan dari cahaya dan malaikat tidak mampu menjelaskan nama-nama benda. Untuk membuktikan ayat ini, penulis mengambil tiga ayat relevan, yakni: QS. al-Mu'minun (24): 12 (sari pati tanah); QS. al-Hijr (15): 26 (lumpur); dan QS. al-Rahman (55): 14 (tanah kering seperti tembikar). Unsur pembentuk manusia berdasarkan tiga ayat di atas adalah tanah, air (lumpur $=$ tanah + air), dan tembikar. Unsur tanah terdiri dari besi $(\mathrm{Fe})$, tembaga $(\mathrm{Cu})$, kobalt $(\mathrm{Co})$, Mangan $(\mathrm{Mn})$ dan unsur air hidrogen $(\mathrm{H})$, nitrogen $(\mathrm{N})$, fosfor $(\mathrm{P})$, dan oksigen $(\mathrm{O})$. Semua unsur-unsur metal dan metaloid akan menjadi katalis dalam proses reaksi kimia dan biokimia untuk membentuk molekul yang lebih komplek, seperti ureum, asam amino, dan nukleotida yang berfungsi sebagai pendukung proses kehidupan. Sementara tembikar digunakan sebagai katalis dalam proses perpanjangan rantai kimia (polimer) dari molekul menjadi makromolekul, supramakromolekul, dan jaringan sel tubuh, termasuk sel otak, dan DNA. Sel otak inilah yang kemudian berfungsi menyimpan informasi, sementara DNAkromosom berfungsi menyimpan informasi genetik manusia. ${ }^{36}$

Contoh lain dalam hal ini adalah pengungkapan beberapa fakta sains tentang Nabi Nuh, di antaranya: [1] QS. al-Qamar (54): 13 tentang ukuran bahtera Nabi Nuh yang diperkirakan oleh ilmuwan memiliki panjang 150 meter, lebar 75, dan tinggi 15 meter. ${ }^{37}$ [2] QS. Hūd (11): 44 mengenai tempat berlabuhnya bahtera Nabi Nuh di Gunung Judi. Pada tahun 1994 fakta ini berhasil diungkap oleh tim ekspedisi yang

${ }^{36}$ Ibid., 32-33.

${ }^{37}$ Ibid., $60-62$. dipimpin oleh David Fasold, seorang ahli geofisika asal AS dan Salih Bayraktutan, direktur institut geologi Universitas Ataturk, Turki, melalui foto sebuah objek berbentuk kapal yang terkubur di kedalaman 2.3000 meter di Gunung Judi. ${ }^{38}$ [3] QS. al-'Ankabut (29): 14-15 menyangkut usia Nabi Nuh yang mencapai 950 tahun, berdasarkan pendapat Balsiger dan Sellier yang menyatakan bahwa sebelum banjir besar atmosfir masih diselimuti oleh lapisan kanopi air yang berfungsi melindungi manusia dari radiasi ultraviolet. Setelah banjir besar kanopi ini turun ke bumi yang mengakibatkan lapisan atmosfir menjadi tipis dan menyebabkan umur manusia menjadi lebih pendek, seperti Nabi Ibrahim, hanya berusia 100 tahun, ${ }^{39}$ bahkan Nabi Muhammad SAW hanya berumur 63 tahun.

Sistematika penyajian seperti diuraikan di atas adalah berbentuk deduktif-konfirmatif, yang menempatkan temuan ilmiah sebagai penjelas ayat-ayat al-Qur'an yang dipandang relevan. Namun, perlu digarisbawahi bahwa tidak semua ayat-ayat al-Qur'an termasuk ayatayat kauniyah, dapat dijelaskan melalui sains. Hal ini bisa disebabkan oleh keterbatasan sains yang mungkin belum mampu diungkapkan. Selain itu, juga bisa disebabkan oleh sifat-sifat ayat-ayat al-Qur'an yang secara faktual tidak bisa dijelaskan secara empiris melalui sains.

\section{Teologi sebagai Basis Integrasi}

Menurut Sardar, konsep ilmu dalam Islam diintegrasikan melalui nilai-nilai, artinya ada wawasan faktual pada satu sisi dan metafisik di sisi lain yang dapat digabungkan melalui sintesis secara berimbang. ${ }^{40}$ Islam harus dilihat bukan hanya sebagai iman dan agama, akan tetapi pandangan realitas dunia secara holistik. Islam berinteraksi dengan realitas kontemporer melalui matriks nilai-

\footnotetext{
${ }^{38}$ Ibid., 66-71.

${ }^{39}$ Ibid., 72.

${ }^{40}$ Ziauddin Sardar dan Ehsan Masood, 47-48.
} 
nilai keesaan Tuhan. Seyyed Hossein Nasr mengungkapkan:

... May the new edition help those who are concerned with the question of Islamic science in its relation to Islamic civilization as well as the relation between Islam and science today to benefit from those wise Muslim scientists, savants and hakims whose thoughts and words are translated and studied in this book. Their thoughts and words are precious because they transmit to us a science which is always rooted in God while studying His creation; a science which reflects systematic knowledge of nature without ever forgetting the Author of Nature Who has inscribed His Wisdom upon every leaf and stone and who has created the world of nature in such a way that every phenomenon is a sign (ayah) singing in silent music the glory of His Oneness. ${ }^{41}$

Melalui ungkapan di atas, Nasr ingin menawarkan integrasi keilmuan berbasis teologi. Ilmu senantiasa berakar pada Tuhan, di mana ia ditempatkan dalam prinsip tauhid yang memperlihatkan adanya kesatuan wujud semesta, karena pada dasarnya semua pengetahuan berasal dari Tuhan. Tujuan semua ilmu keislaman adalah untuk menunjukkan kesatuan dan hubungan baik dari semua yang ada sehingga dalam merenungkan kosmos, manusia senantiasa diarahkan pada kesatuan prinsip ilahi. Oleh karena itu, untuk memahami hubungan fungsional lintas ilmu, manusia harus menempatkan prinsip-prinsip ilahi sebagai sesuatu yang integral yang tidak bisa berdiri sendiri. ${ }^{42}$

Tafsir Ilmi tidak terlepas dari prinsip teologi seperti yang dikemukakan di atas.

\footnotetext{
${ }^{41}$ Seyyed Hossein Nasr, hlm. xiv-xv.

${ }^{42}$ Ibid., 22-23.
}

Terlebih ia merupakan representasi dari ayāt Tuhan, baik yang tersurat dalam bentuk teks al-Qur'an maupun yang tersirat di alam semesta. ${ }^{43}$ Tuhan di tempatkan sebagai posisi sentral dalam kajian Tafsir Ilmi. Segala sesuatu yang berkaitan dengan bahasan selalu berkaitan dengan Tuhan dengan segala bentuk sifat dan keagungan-Nya. Secara sederhana dapat dilihat dalam diagram di bawah:

Diagram 2. Posisi Teologi dalam Tafsir

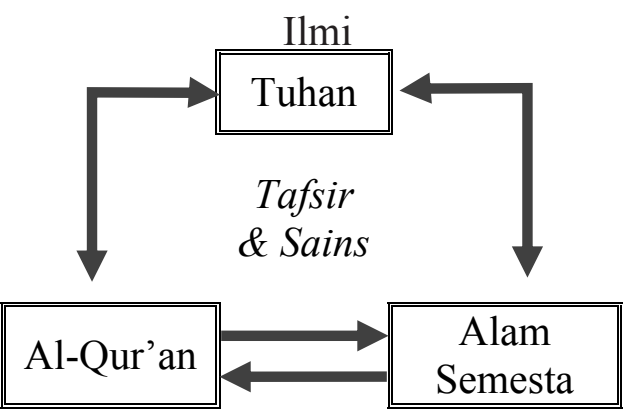

Pada gambar di atas, Tuhan adalah entitas transenden yang selalu berhubungan dengan al-Qur'an dan Alam Semesta sebagai wujud yang integral. Sementara al-Qur' an memiliki keterkaitan satu sama lain, di mana hubungan tersebut dikukuhkan melalui pembacaan tafsir dan sains. Sebagai contoh, dalam buku Penciptaan Bumi, bumi digambarkan sebagai bentuk kesempurnaan kerajaan dan kekuasaan Allah yang tertib, teratur, dan sempurna. ${ }^{44}$ Allah sebagai Pencipta kemudian menjadikan sunatullah sebagai hukum alam yang menjaga ketertiban, keteraturan dan kesempurnaan ciptaan-Nya. ${ }^{45}$ Di samping itu, Allah juga menjadikan agama sebagai

43Bagi Mulyadhi, sumber primer ilmu agama (naqliyah) didasarkan pada otoritas, yakni al-Qur'an dan hadis. Sementara sumber ilmu umum (aqliyah) adalah alam semesta. Keduanya, baik al-Qur'an maupun alam semesta adalah ayat Tuhan. Oleh karena itu, segala ilmu pada prinsipnya bersumber dari Tuhan. Klasifikasi Ilmu menjadi Ulūm al-naqliyah dan Ulüm al-aqliyah oleh Mulyadhi ini merujuk pada pendapat Ibn Khaldun, lihat: Mulyadhi Kartanegara, 47-48.

${ }^{44}$ QS. al-Mulk (67): 1-5.

${ }^{45}$ QS. Lukman (30): 10. 
hukum dan ketentuan bagi manusia untuk meraih kebahagiaan dunia dan akhirat. Untuk memahami kesempurnaan ciptaan-Nya, manusia diberi akal, dalam pengertian memiliki landasan iman, selalu ingat ketentuan Allah dan senantiasa memikirkan alam ciptaan-Nya. ${ }^{46}$ Dengan demikian, manusia dapat membuktikan betapa ciptaan-Nya itu memiliki sisi manfaat yang luar biasa bagi kehidupan manusia, baik dari sisi keteraturannya, maupun kelayakannya sebagai tempat yang nyaman untuk dihuni. ${ }^{47}$

Sisi teologis dalam paradigma Islam dan sains modern oleh Muzaffar Iqbal merupakan salah satu ciri khas sains Islam. Ia menyebutnya sebagai ontological/metaphysical, bahwa hal mendasar dalam Islam dan sains modern adalah adanya analisis metafisik. Natural sains berikut datanya dikumpulkan melalui alat ilmiah ataupun observasi, kemudian dilakukan pemeriksaan secara ditail melalui wahyu. ${ }^{48}$ Analisa semacam ini bagi Muzaffar akan menghadirkan nilai-nilai universal, di mana nilai tersebut tidak saja diyakini oleh umat Islam, namun juga dapat diakui oleh agama-agama lain.

Penjelasan Tafsir Ilmi tentang eksistensi manusia sebagai makhluk cerdas, misalnya Surat al-Tin (95): 4. Ayat tersebut menjelaskan bahwa manusia merupakan ciptaan yang paling sempurna. Isyarat ini kemudian dibuktikan melalui temuan ilmiah mengenai otak manusia. Data sains mengungkap bahwa otak manusia dapat merekam informasi sebanyak $10^{17} 10^{17}$ bit atau $10^{7}$ bit, setara dengan 2 juta buku setebal 500 halaman. Sistem saraf pada otak akan senantiasa berkembang. Super komputer tercanggih sekalipun tidak akan melebihi sistem saraf pada siput, apalagi sistem saraf pada manusia. ${ }^{49}$

\footnotetext{
${ }^{46}$ QS. Ali Imran (3): 190-191.

${ }^{47}$ Lajnah Pentashihan Mushhaf al-Qur'an, Penciptaan Bumi dalam Perspektif al-Qur'an dan Sains (Jakarta: LPMA, 2010), 4-17. ${ }^{48}$ Muzaffar Iqbal, 198.

${ }^{49}$ Lajnah Pentashihan Mushhaf al-Qur'an, Kehidupan di Alam Semesta dalam Perspektif al-Qur'an dan Sains (Jakarta: LPMA,
}

Hal ini kemudian menghadirkan nilai universal bahwa ada kekuatan di luar diri manusia yang berperan menciptakan kemampuan yang luar biasa itu. Hal ini senada dengan apa yang diinginkan oleh Seyyed Hossein Nasr, bahwa metafisika dapat menghubungkan berbagai tingkatan ilmu hingga sampai pada hakikat pengetahuan yang sesungguhnya. ${ }^{50}$

Selain itu, Tafsir Ilmi juga memiliki fungsi teologis, salah satunya adalah dapat menjadi media untuk memperkenalkan Tuhan. Muchlis M. Hanafi menyebutnya sebagai "ilmu kalam baru". ${ }^{51}$ Jika pada masa tradisional Islam, Tuhan diperkenalkan melalui logika ilmu kalam yang menempatkan rasio untuk mengkonfirmasi kebenaran wahyu. Maka pada masyarakat modern, pendekatan ini dipandang sudah kurang relevan. Oleh sebab itu, kedekatan manusia modern dengan perkembangan ilmu pengetahuan dan teknologi dapat dimanfaatkan untuk tujuan yang sama.

\section{Dari Teologi Menuju Etika}

Salah satu tujuan penting proyek integrasi keilmuan dalam Islam selain mengakhiri dikotomi ilmu adalah melahirkan etika sains, agar ia tidak bebas nilai. Hampir semua ilmuwan yang disebutkan di atas menyuarakan hal tersebut. Hal ini berangkat dari fenomena sains Barat yang tidak berpihak pada isu moralitas dan etika sains yang diklaim value free dan sarat dengan berbagai kepentingan, baik kepentingan politik, ekonomi, militer, dan lain-lain. Berbeda dengan sains Islam, menurut Sardar, baik hasil, sarana, tujuan, proses, metode senantiasa berada pada pusaran sistem etika. ${ }^{52}$ Sebuah sains dianggap

\footnotetext{
2015), 45-49.

${ }^{50}$ Seyyed Hossein Nasr, The Need For a Sacred Science (UK: Curzon Press, 2005), 86.

${ }^{51}$ Muchlis M. Hanafi, "Memahami Isyarat-isyarat Ilmiah alQur'an: Sebuah Pengantar" dalam Lajnah Pentashihan Mushaf al-Qur'an, Hewan dalam Perspektif al-Qur'an dan Sains, xviii.

${ }^{52}$ Ziauddin Sardar dan Ehsan Masood, 120.
} 
"Islami" selama memberikan kemaslahatan bagi seluruh manusia dan tidak destruktif baik bagi individu, masyarakat, dan lingkungan.

Etika sains Islam dirumuskan melalui paradigma teologis yang memandang bahwa manusia adalah wakil Tuhan (khalifah) di muka bumi. Sebagai khalifah, manusia diberi amanah untuk menjaga dan memelihara eksistensi bumi. ${ }^{53}$ Dalam pandangan Sardar, status khalifah yang diberikan Tuhan kepada manusia dapat dijadikan matrik dalam interaksi Islam dan realitas kontemporer, termasuk sains. Ketika problem kontemporer dianalisis melalui perangkat etika dan nilai-nilai moral, akan terjadi transformasi syariat, dari aturan dan perintah secara dogmatis menjadi metodologi pemecahan masalah multidimensi.

Dalam konteks sains modern, Islam memandang bahwa ilmu pengetahuan adalah entitas yang tidak terpisah dari moralitas. Ilmu beroperasi pada wilayah tauhid, di mana ia diperoleh untuk memuliakan Allah pada satu sisi dan untuk memenuhi tanggung jawab manusia sebagai khalifah di sisi lain. Oleh sebab itu, tauhid, ilmu pengetahuan, dan khalifah memiliki hubungan secara integral dan menjadi instrumen bagi lahirnya nilai-nilai etika. Secara sederhana dapat digambarkan sebagai berikut:

Diagram 3. Etika Sains Islam

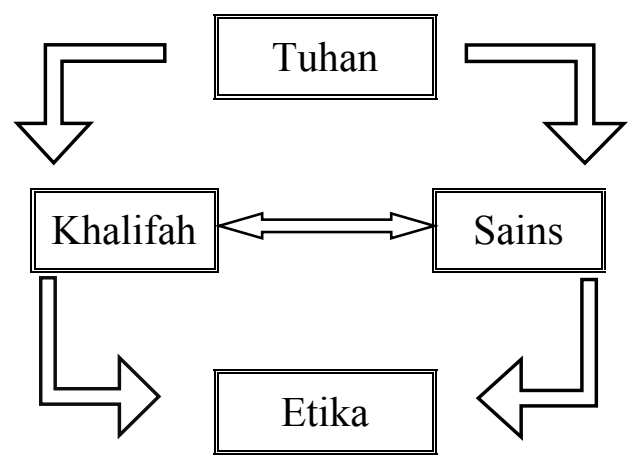

Kehadiran Tafsir Ilmi pada prinsipnya berkontribusi bagi rekonstruksi nilai-nilai etika yang akhir-akhir ini menggerus semua lini kehidupan masyarakat Indonesia. Persoalan lingkungan hidup misalnya, Tafsir Ilmi: Air dalam Perspektif al-Qur'an dan Sains disebutkan bahwa Allah telah memberikan anugerah air bagi keberlangsungan kehidupan di bumi. Al-Qur'an dan sains membuktikan bahwa air memiliki manfaat yang luar biasa bagi kehidupan, baik sebagai stabilisator suhu bumi, ${ }^{54}$ asal, dan penyangga kehidupan, ${ }^{55}$ air hujan yang menghidupkan, ${ }^{56}$ serta memberikan manfaat langsung bagi kehidupan. ${ }^{57}$ Manfaat air yang luar biasa ini akan sirna jika manusia tidak mampu menempatkan nilai-nilai etika dalam pemanfaatannya. Akan terjadi banjir, erosi, kekeringan, pencemaran air, dan kerusakan lingkungan lainnya.

Nur Arfiyah Febriani menilai bahwa terjadinya kerusakan alam disebabkan oleh adanya pandangan manusia yang antroposentris. Paradigma ini kering nilainilai moral dan spiritual. Ia kemudian menawarkan paradigma ekohumanisteosentris yang memungkinkan terjadinya relasi harmonis, baik dengan diri sendiri, sesama manusia, alam, dan Tuhan sebagai pencipta ${ }^{58}$ Dalam kaitan ini nilai etika tidak sepenuhnya bersandar pada rasio manusia, namun ia terikat oleh norma-norma dan nilai-nilai. Norma dan nilai tersebut akan membangkitkan kesadaran manusia untuk menjaga dan melestarikan sumber daya air sebagai penyangga kehidupan. Sebab eksploitasi alam para prinsipnya tidak saja

\footnotetext{
${ }^{54} \mathrm{QS}$. al-Mu'minūn (23): 18.

${ }^{55}$ QS. al-Anbiyā' (21) :30; al-Baqarah (2): 164; al-Nūr (24): 45; dan al-Furqān (25): 54.

${ }^{56} \mathrm{QS}$. al-Rūm (30): 24.

${ }^{57}$ Manfaat langsung air bagi kehidupan manusia adalah untuk metabolisme tubuh dan kesejahteraan manusia, seperti alat transportasi, pembangkit energi. Lihat, Lajnah Pentashihan Mushhaf al-Qur'an, Air dalam Perspektif al-Qur'an dan Sains (Jakarta: LPMA, 2010), 62-88.

${ }^{58}$ Nur Arfiyah Febriani, Ekologi Berwawasan Gender dalam Perspektif al-Qur'an (Bandung: Mizan, 2014), 11-13.
} 
berdampak negatif bagi alam itu sendiri, namun merusak tatanan relasi antara sesama manusia, dan bahkan relasi dengan Tuhan.

Contoh lain, dalam buku Seksualitas dalam Perspektifal-Qur'an dijelaskan bahwa sudah menjadi fitrah manusia diciptakan secara biologis berpasang-pasangan. Tujuannya adalah untuk melestarikan keberlangsungan spesies manusia. ${ }^{59}$ Penyimpangan seksual seperti lesbian, gay, biseksual, transgender atau yang dikenal dengan singkatan LGBT adalah bentuk tindakan yang keluar dari fitrah manusia dan keluar dari nilainilai etika Islam. Kehadiran Tafsir Ilmi tentang seksualitas, pada prinsipnya ingin mendakwahkan nilai-nilai tersebut di tengahtengah masyarakat modern yang cenderung mengikuti hawa nafsu tanpa menyadari akan fitrahnya. Fitrah menjadi instrumen untuk menggugah kesadaran manusia, bahwa ada nilai ketuhanan dan etika yang harus dipatuhi dan diimplementasikan dalam kehidupan. Caranya adalah menyalurkan kebutuhan biologis sesuai dengan aturanNya, melakukan hubungan seks hanya dengan pasangan yang sah dan memenuhi etika hubungan seksual itu sendiri.

\section{Kesimpulan}

Tafsir Ilmi Kementerian Agama merupakan salah satu representasi dari implementasi paradigma integrasi agama dan sains, khususnya di bidang tafsir. Paradigma Integrasi dalam Tafsir Ilmi tidak hanya ingin menunjukkan bahwa tidak ada dikotomi antara agama dan sains, lebih dari itu ia merupakan salah satu bentuk upaya memperkenalkan Tuhan kepada masyarakat modern melalui pertemuan tafsir dan sains. Hal ini dapat dilihat dari pola penerapan integrasi yang disuguhkan, teologi senantiasa hadir untuk menjelaskan berbagai makna ayat dan kemudian dipertegas melalui temuan ilmiah.

\footnotetext{
${ }^{59}$ Lajnah Pentashihan Mushhaf al-Qur'an, Seksualitas dalam Perspektif al-Qur'an dan Sains (Jakarta: LPMA, 2010), 15.
}

Sistematika semacam ini jelas memiliki efek kuasa bagi pembaca, sehingga pembaca secara tidak sadar digiring untuk membenarkan dan meyakini ayat-ayat al-Qur'an untuk kemudian diterjemahkan dalam kehidupan sehari-hari. Selain itu, pola integrasi yang menjadikan teologi sebagai basisnya, tidak saja menggugah keyakinan, namun juga melahirkan nilai-nilai etika. Perpaduan konsep tauhid, khalifah, dan ilmu pengetahuan modern memiliki hubungan fungsional dalam menghadirkan nilai-nilai etika itu. Etika yang dihadirkan sebagai upaya memberikan nilai pada ilmu (free value), dan secara praktis etika tersebut memiliki fungsi untuk menjaga relasi manusia dengan dirinya sendiri, dengan sesama manusia, dengan Sang Pencipta.

Umat Islam boleh berbangga dengan karya Tafsir Ilmi ini. Ia merupakan karya nyata dari buah integrasi agama dan sains. Meskipun demikian, umat Islam tidak boleh berhenti pada tatanan integrasi. Produktivitas mandiri umat Islam dalam menghasilkan sains juga harus menjadi prioritas. Dalam ungkapan lain, umat Islam tidak boleh terlena dalam kemajuan sains yang pernah dicapai oleh sarjana-sarjana terdahulu yang telah sukses menghasilkan kerangka mandiri sains Islam dan pasif dalam menerima temuan sains modern untuk kemudian hasil tersebut dapat dipertemukan dengan teks al-Qur'an. Ke depan bagaimana mengupayakan agar umat Islam produktif, inovatif, dan kreatif dalam melahirkan sains Islam mandiri.

Tulisan ini baru melihat penerapan paradigma integrasi dalam Tafsir Ilmi, baik secara epistemologi, metafisika, dan etika. Masih banyak objek, baik formal maupun material yang belum tersentuh. Peneliti berikutnya dapat secara spesifik menggunakan paradigma lain untuk membaca karya ini. Ada 16 judul Tafsir Ilmi, salah satu di antaranya dapat dijadikan objek penelitian secara khusus dengan menggunakan pendekatan yang relevan. 


\section{Daftar Kepustakaan}

Abdul Mustaqim. Metode Penelitian al-Qur'an dan Tafsir. Yogyakarta: Idea Press, 2015.

AE. Priyono (ed.). Paradigma Islam: Interpretasi untuk Aksi. Bandung: Mizan, 2008.

Barbour, Ian G. When Science Meets Religion. New York: Harper Collins Francisco, 1998.

al-Dzahabi, Muhammad al-Said Husain. al-Tafsīr wa al-Mufassirūn. Al-Qāhirah: Maktabah Wahbah, t.th [Maktabah Syamilah].

Efron Lumban Gaol. "Integrasi Sains dan Agama: Sebuah Tawaran dari Ken Wilber untuk Zaman Ini”. MELINTAS 28, no. 3 (2012). http://journal.unpar. ac.id/index. $\mathrm{php} / \mathrm{melintas} /$ article/viewFile/274/259. Diakses 21 Desember 2016.

Fahruddin Faiz. Hermeneutika al-Qur'an: Tema-tema Kontroversial. Cet. Ke-V. Yogyakarta: eLSAQ Press, 2011.

Fuad, dkk. "Kebenaran Ilmiah dalam Pemikiran Thomas S. Kuhn dan Karl R. Popper: Suatu Kajian Hermeneutika dan Kontribusi nya bagi Masa Depan Ilmu. Jurnal Filsafat 23, no. 2 (2015). https://jurnal.ugm.ac.id/ wisdom/article/view/12684/9119. Diakses 21 Desember 2016.

http://www.putramelayu.web.id/2015/02/ mengenang-altavista-mesin-pencari-yang. html. Diakses 28 Des 2016.

https://search.yahoo.com. Diakses 28 Des 2016 melalui kata kunci "Islam and Science".

Iqbal, Basit Kareem dan Halder, Elma. "Islam and Science Online". Islamic Studies 39, no. 4 (2000). http://www.jstor.org/ stable/23076120. Diakses 28 Desember 2016.

Iqbal, Muzaffar. Making of Islamic Science. London: Greenwood Press, 2007.
Islah Gusmian. Khazanah Tafsir Indonesia: Dari Hermeneutika Hingga Ideologi. Yogyakarta: LKiS, 2013.

Kaelan. Metode Penelitian Agama Kualitatif Interdisipliner. Yogyakarta: Paradigma, 2010.

Kuntowijoyo. Islam Sebagai Ilmu: Epistemology, Metodologi dan Etika. Bandung: Teraju, Mizan Media Utama 2004.

Kusmana. „Paradigma al-Qur'an: Model Analisis Tafsir Maqashidi dalam Pemikiran Kuntowijoyo". Afkaruna 11, no. 2 (2015). http://journal.umy.ac.id/index. php/afkaruna/article/viewFile/2210/2147. Diakses 25 Desember 2016.

Lajnah Pentashihan Mushaf al-Qur'an. Hewan dalam Perspektif al-Qur'an dan Sains. Jakarta: LPMA, 2012.

Kisah Para Nabi Pra-Ibrahim dalam perspektif al-Qur'an dan Sains. Jakarta: LPMA, 2012.

-------. Penciptaan Bumi dalam Perspektif alQur'an dan Sains. Jakarta: LPMA, 2010.

- Kehidupan di Alam Semesta dalam Perspektif al-Qur'an dan Sains. Jakarta: LPMA, 2015.

------. Air dalam Perspektif al-Qur'an dan Sains. Jakarta: LPMA, 2010.

-------. Seksualitas dalam Perspektif al-Qur'an dan Sains. Jakarta: LPMA, 2010.

-------. Penciptaan Jagad Raya dalam Perspektif al-Qur'an dan Sains. Jakarta: LPMA, 2010.

-------. Penciptaan Manusia dalam PerspektifalQur'an dan Sains. Jakarta: LPMA, 2010.

-------. Tumbuhan dalam Perspektif al-Qur'an dan Sains. Jakarta: LPMA, 2010.

-------. Kiamat dalam Perspektif al-Qur'an dan Sains. Jakarta: LPMA, 2010. 
-------. Manfaat Benda-benda Langit dalam Perspektif al-Qur'an dan Sains. Jakarta: LPMA, 2012.

-------. Makanan dan Minuman dalam Perspektif al-Qur'an dan Sains. Jakarta: LPMA, 2013.

-------. Samudra dalam Perspektifal-Qur'an dan Sains. Jakarta: LPMA, 2013.

Waktu dalam Perspektif al-Qur'an dan Sains. Jakarta: LPMA, 2013.

-------. Jasad Renik dalam Perspektif al-Qur'an dan Sains. Jakarta: LPMA, 2015.

------. Kepunahan Makhluk Hidup dalam Perspektif al-Qur'an dan Sains. Jakarta: LPMA, 2015.

M. Amin Abdullah. Islamic Studies di Perguruan Tinggi: Pendekatan IntegratifInterkoneksi. Yogyakarta: Pustaka Pelajar, 2006.

Mulyadhi Kartanegara. Integrasi Ilmu: Sebuah Rekonstruksi Holistik. Jakarta: UIN Jakarta Press, 2005.

Muslim, Mushthafa. Mabāhits fi al-Tafsīr alMawdhū'iy. Dimāsyq: Dār al-Qalm, 1989.

Nasr, Seyyed Hossein. Science and Civilization in Islam. New York: New American Library, 1970.

-------. The Need For a Sacred Science. UK: Curzon Press, 2005.

Nur Arfiyah Febriani. Ekologi Berwawasan
Gender dalam Perspektif al-Qur'an. Bandung: Mizan, 2014.

Parluhutan Siregar. "Integrasi Ilmu-ilmu Keislaman dalam Perspektif M. Amin Abdullah". MIQOT: Jurnal Ilmu-ilmu Keislaman 38, no. 2 (2014). http://www. jurnalmiqotojs.uinsu.ac.id/index.php/ jurnalmiqot/article/view/66. Diakses 21 Desember 2016.

Peacock, Arthur. Paths From Science Towards God. New York: One world Publications, 2001.

Saifuddin Zuhri. "Integrasi Biologi dan Agama dalam Perspektif Islam". Disertasi tidak Dipublikasikan. Sekolah Pascasarjana UIN Syarif Hidayatullah Jakarta, 2009.

Sardar, Ziauddin dan Ehsan Masood. How Do You Know: Reading Ziauddin Sardar on Islam, Science and Cultural Relations. London: Pluto Press, 2006.

Suwendi. "Islamisasi Ilmu: Studi atas Konsep dan Praktek Pendidikan Syed Muhammad Naquib al-Attas". Disertasi tidak Dipublikasikan. Sekolah Pascasarjana UIN Syarif Hidayatullah Jakarta, 2008.

Wilber, Ken. The Marriage of Sense and Soul: Integrating Science and Religion. New York: Random House, 1998.

Zainal Abidin Bagir, dkk (ed.). Integrasi Ilmu dan Agama: Interpretasi dan Aksi. Bandung: Mizan, 2005. 